\title{
Utilization of Cement Kiln Dust (CKD) as a Partial Replacement of Cement in Mortar and Concrete
}

\author{
I. H. Hassan \\ Lecturer
}

\author{
O. M. Abdul-Kareem \\ Lecturer
}

\author{
Ahmed Yasin Shihab \\ Lecturer
}

\begin{abstract}
This research examines the potential of using cement kiln dust (CKD) as a blended cement material to study the effects of this partial replacement on the most important properties of cement paste, mortar and concrete. The levels of replacement of cement by an equal amount of the (CKD) dust were $(5,10,15,20,25,30) \%$ by weight. A reference cement paste, mortar and concrete mix were also prepared for comparison. The tested properties included the initial setting time of each cement paste and the compressive and tensile strengths of mortars and concrete. Water curing was used for all specimens and the strength tests were carried out at $(3,7,28)$ days. Results of experimental data reveal that $(\mathrm{CKD})$ can be effectively used as a partial cement material. The initial setting time of the cement paste is decreased with the increase of (CKD) content due to the high amount of lime and alkalis in (CKD). Besides, the compressive and tensile strengths of the blended cement and concrete specimens were also found to be comparable to the strengths of the reference mixes at all levels of replacement. Generally, it was indicated that the compressive strength decreased with the increase of (CKD) content. The (10)\% replacement level had the best results in the compressive strengths of mortars and concretes at all ages in comparison to the reference mixes, also this level of substitution had a significant effect on the tensile strength of the mortars and concretes at early ages. It was noted that (15)\% (CKD) replacement maintained the higher tensile strength of mortars at $(7,28)$ days, whereas a $(25) \%$ (CKD) had a similar effect but at $(3,28)$ days.
\end{abstract}

Keywords: Cement Kiln Dust (CKD), Partial Replacement, Utilization.

$$
\begin{aligned}
& \text { الاستفادة من غبار فرن السمنت (CKD) كبديل جزئي عن السمنت في المونة والخرسانة }
\end{aligned}
$$

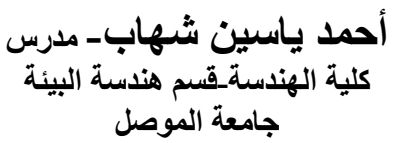

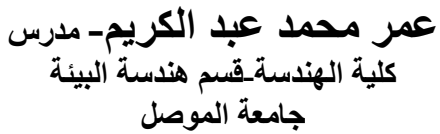

$$
\begin{aligned}
& \text { كلية الهندسةمةقازم الهندسة المدنية }
\end{aligned}
$$

يتضمن هذا البحث دراسة إمكانية استخدام غبار فرن السمنت كمادة سمنتية ممزوجة لاراسـة تأثثر الاستبدال الجزئي الفئي

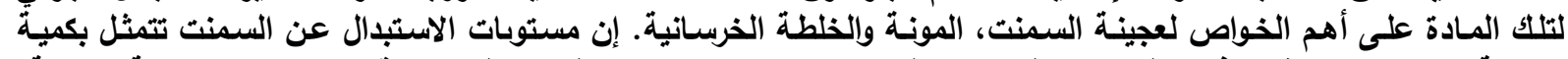

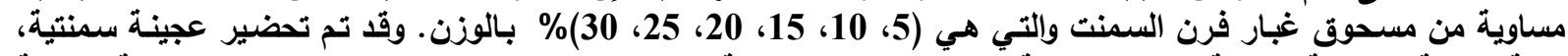

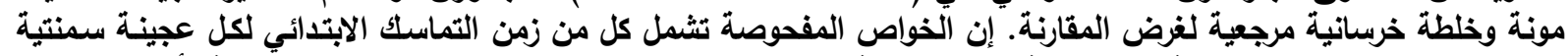

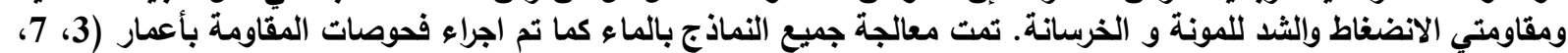

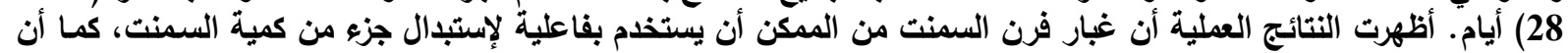

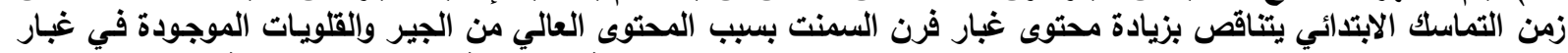

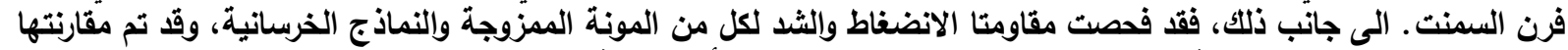

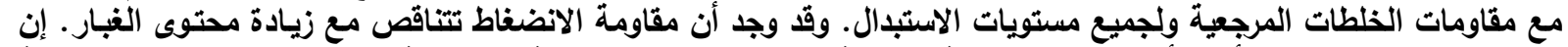

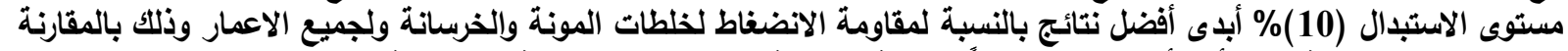

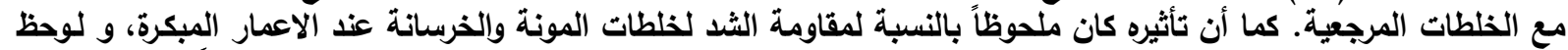

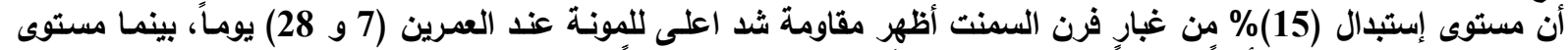
\%) من الغبار حقق تأثيراً مشابهاً للنماذج الخرسانية بعمر (35 و 28) يوماً. 


\section{INTRODUCTION}

Portland cement is the most widely used construction material in the world. Each year, the concrete industry produces approximate 12 billion tons of concrete and uses about 1.6 billion tons of portland cement worldwide [1]. As with most large manufacturing industries, by-product materials are generated. These industrial by-product and waste materials must be managed responsibly to insure a clean and safe environment [2]. The volume of by-product materials generated from core-sector industries such as cement, power, steel, and other mining and heavy industries are increasing. The cost of disposal is continuing to grow dayby-day in our society. The growth of by-product materials is inevitable unless new and beneficial use options, which are economically sound and environmentally friendly, are developed and implemented [3]. The cement industry has a limited number of by-products that result from the manufacturing process. The most voluminous by-product generated is cement kiln dust (CKD) [4].

Cement kiln dust (CKD) is a fine material produced as a result of cement production. (CKD) often consists of clinker particles, partially calcined materials and alkali compounds, which can be high in lime content. These particulates are captured by the exhaust gases and collected in particulate matter control devices such as cyclones, baghouses and electrostatic precipitators, Fig.(1) [2]. Cement kiln dust is often used as the generic term for dust created in the kiln and collected from the cement manufacturing process. Wet kilns produce more net (CKD) than dry kilns. Portions, and in some cases all, of the dust collected by particulate matter control devices (PMCD) is returned to the manufacturing process. Approximately 64\% of all (CKD) generated is recycled. Dust that is not returned to the process is done so because of the accumulation of alkalis and heavy metals that exceed final product chemical tolerances, or simply because there is a lack of mechanization to return the dust to the process. (CKD) that is not returned to the system is placed in landfills on site, or preferably, may be sold for beneficial uses [5]. These beneficial uses included base stabilizing for pavement, waste water treatment, waste remediation, low strength backfill, and municipal landfill cover [2].

In a wet process, some of the (CKD) is removed from the kiln as waste dust. In a dry process, dust is collected from the kiln in precipitators. (CKD) removed from the clinker cooler at the end of the kiln is recirculated in the cyclone and preheaters. Dust collected from the upstream portion of the kiln is removed from the system as by-pass dust. The by-pass 4 dust is removed as a precaution against materials (heavy metals, chlorides, and alkalis) that may cause the clinker to be out of specification limits. Figs.(2) and (3) show portions of a kiln in a wet process and a dry process, respectively [5].

In the wet process, the raw materials are introduced into the kiln in a slurry form. With the wet process, there is approximately $30 \%$ dust loss but this can be reduced using mid-kiln injection or insuflation. In the dry process, the raw feed enters the kiln in a powdered form. Since no water has to be driven off, the kiln length is typically shorter in the dry process than in the wet process. In an idealistic dry process, all dust is recirculated. 
Hassan: Utilization of Cement Kiln Dust (CKD) as a Partial Replacement ----

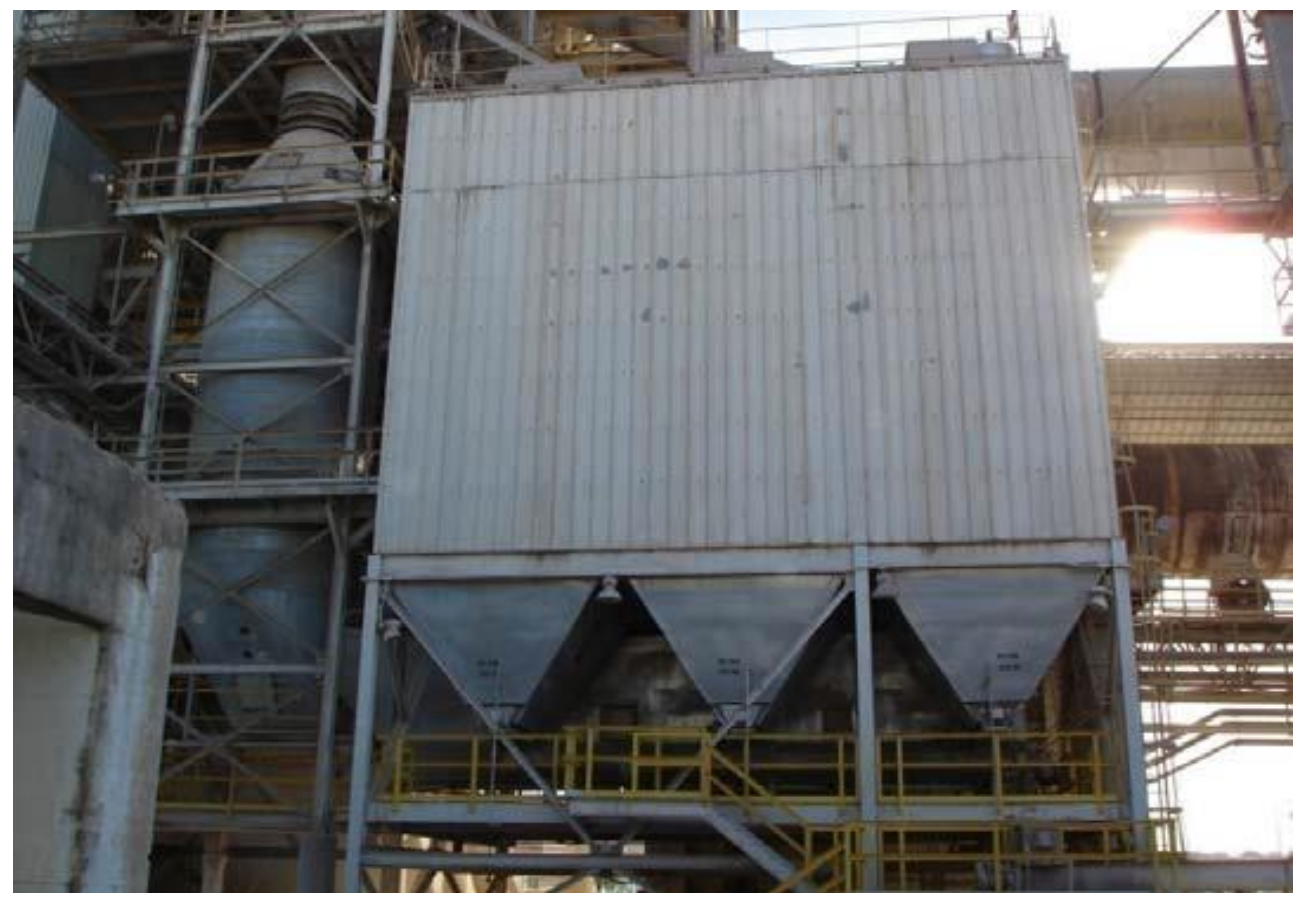

Fig. (1): Dust control device (Courtesy of Capitol Cement

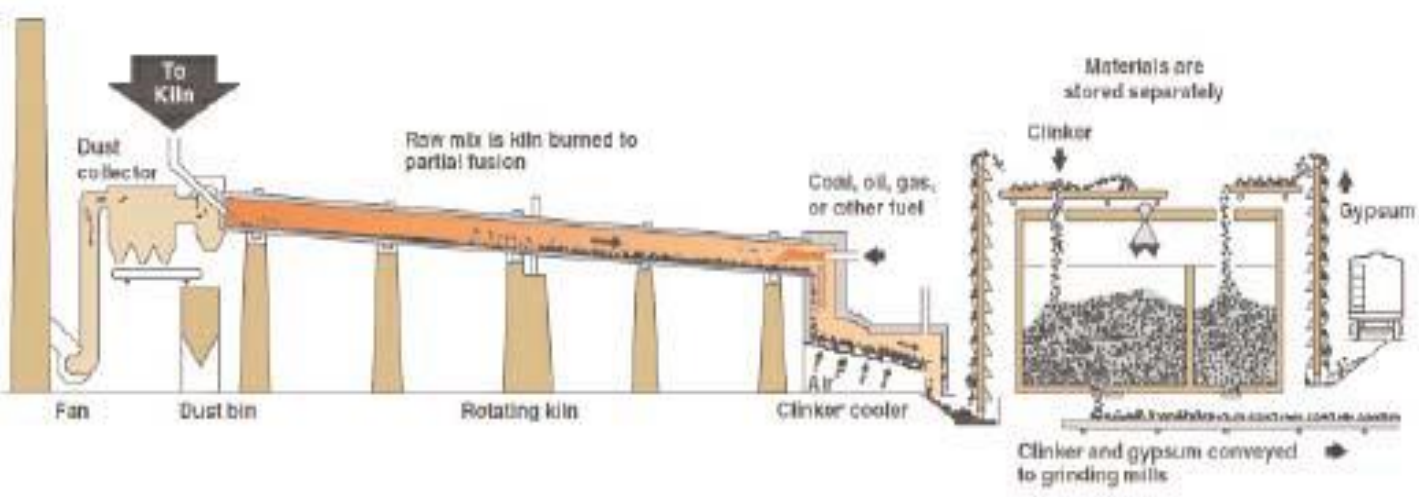

Fig. (2): Schematic of a wet kiln

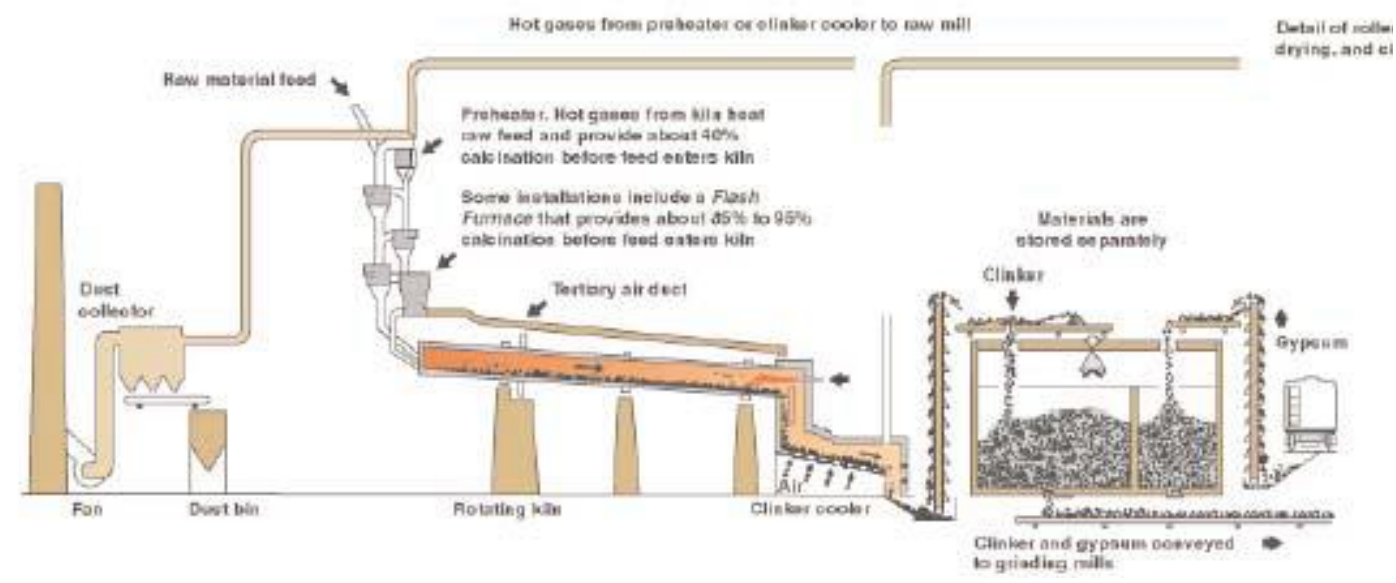

Fig. (3): Schematic of a dry kiln 
Actually, the properties of (CKD) depend on the kind of raw materials and the fuel used, as well as the production method or kiln type [6]. Because plant operations differ considerably with respect to raw feed, type of operation, dust collection facility, and type of fuel used, the use of the terms typical or average (CKD) when comparing different plants can be misleading. The dust from each plant can differ markedly in chemical, mineralogical and physical composition [2].

\section{CKD COMPOSITION}

In general, the composition of (CKD) is similar to that of cement [4]. The data in table (1) indicates that calcium and silica oxides are the major constituents of (CKD), although these values are lower than those found in (OPC). As indicated in table (1), the chemical composition of (CKD) is quite varied due to the uniqueness of the raw materials at each plant. The alkalis $\left(\mathrm{Na}_{2} \mathrm{O}\right.$ and $\left.\mathrm{K}_{2} \mathrm{O}\right)$ and loss on ignition (LOI) are higher in (CKD) than in (OPC), while the calcium oxide $(\mathrm{CaO})$ and the silicate $\left(\mathrm{SiO}_{2}\right)$ contents are lower than that of $(\mathrm{OPC})$. The high (LOI) can indicate that less free lime is available for hydration. (CKD) also tends to be much finer than OPC, which can lead to an increase in the water demand when (CKD) is used as a binder material [5].

Free calcium hydroxide can sometimes appear as calcium hydroxide due to exposure to moisture. It is also observed that (CKD) generally contains higher concentrations of sulfates and alkalis than (OPC). These findings are not surprising since volatiles are preferentially drawn towards (CKD) in the kiln pyroprocess. The alumina, iron, and magnesium concentrations of (CKD) and (OPC) appear to be similar [7].

Table (1): Chemical and Physical Comparison of (CKD) with (OPC) [5]

\begin{tabular}{|c|c|c|}
\hline \multirow{2}{*}{$\begin{array}{c}\text { Chemical } \\
\text { Analysis }\end{array}$} & \multicolumn{2}{|c|}{ Weight } \\
\cline { 2 - 3 } & CKD (\%) & OPC (\%) \\
\hline $\mathrm{SiO}_{2}$ & $11-16$ & 22 \\
\hline $\mathrm{Al}_{2} \mathrm{O}_{3}$ & $3-6$ & 5 \\
\hline $\mathrm{Fe}_{2} \mathrm{O}_{3}$ & $1-4$ & 3 \\
\hline $\mathrm{CaO}$ & $38-50$ & 64 \\
\hline $\mathrm{MgO}$ & $0-2$ & 1 \\
\hline $\mathrm{SO}_{3}$ & $4-18$ & 3 \\
\hline $\mathrm{Na}_{2} \mathrm{O}$ & $0-2$ & $<1$ \\
\hline $\mathrm{K}_{2} \mathrm{O}$ & $3-13$ & $<1$ \\
\hline $\mathrm{Cl}$ & $0-5$ & $<0.1$ \\
\hline $\mathrm{LOI}$ & $5-25$ & 1 \\
\hline $\begin{array}{c}\text { Fineness } \\
\left(\mathrm{m}^{2} / \mathrm{kg}\right)\end{array}$ & $460-1400$ & $300-500$ \\
\hline
\end{tabular}

It was stated that (CKD) is generally off-white or light brown in appearance. The limited number of research studies that provide fineness data typically report Blaine fineness, relative density, and/or particle size distribution. The Blaine fineness values of (CKD) vary in 
the literature between (318) and (1400) $\mathrm{m}^{2} / \mathrm{kg}$, which is generally higher than the typical range of values for (OPC). Comparing the Blaine fineness values has led some researchers to conclude that (CKD) are finer than (OPC). The relative densities of (CKD) which is closer to the density of raw material and less than (3.15) which is the relative density typically assigned to (OPC). (OPC) consists of individual angular particles that are mostly (approximately 95\%) smaller than (45) $\mu \mathrm{m}$. The average particle size of (OPC) particle is approximately (15) $\mu \mathrm{m}$ [7]. As shown in Fig.(4) [8], (CKD) is mainly composed of micron-sized particles. These particles are often agglomerated and very heterogeneous because their chemical composition and particle size distribution depend on raw materials and fuels employed, and on the kiln type in the cement factory [8].

The obvious and best use of (CKD) is its re-incorporation in the clinker production cycle. However, this can only be done when the existing restrictions on the alkalis and chloride concentrations in cement are revised. From alkalis point of view, it is estimated that most of the (CKD) could be utilized in the clinker-making process if the cement alkali levels could be raised by about $(0.1) \%$. Similarly, the limits on the required chloride concentration on the performance of cement in reinforced concrete construction need to be evaluated. The alternative applications of (CKD) include agriculture - potash/lime source and animal feed; civil engineering - fill, soil stabilization, fly ash stabilization, and blacktop filler; building materials - lightweight aggregates, blocks, low strength concrete, and masonry cement; sewage and water treatment; coagulation aid and sludge stabilization and pollution control as sulfur absorbent, waste treatment, and solidification [9].

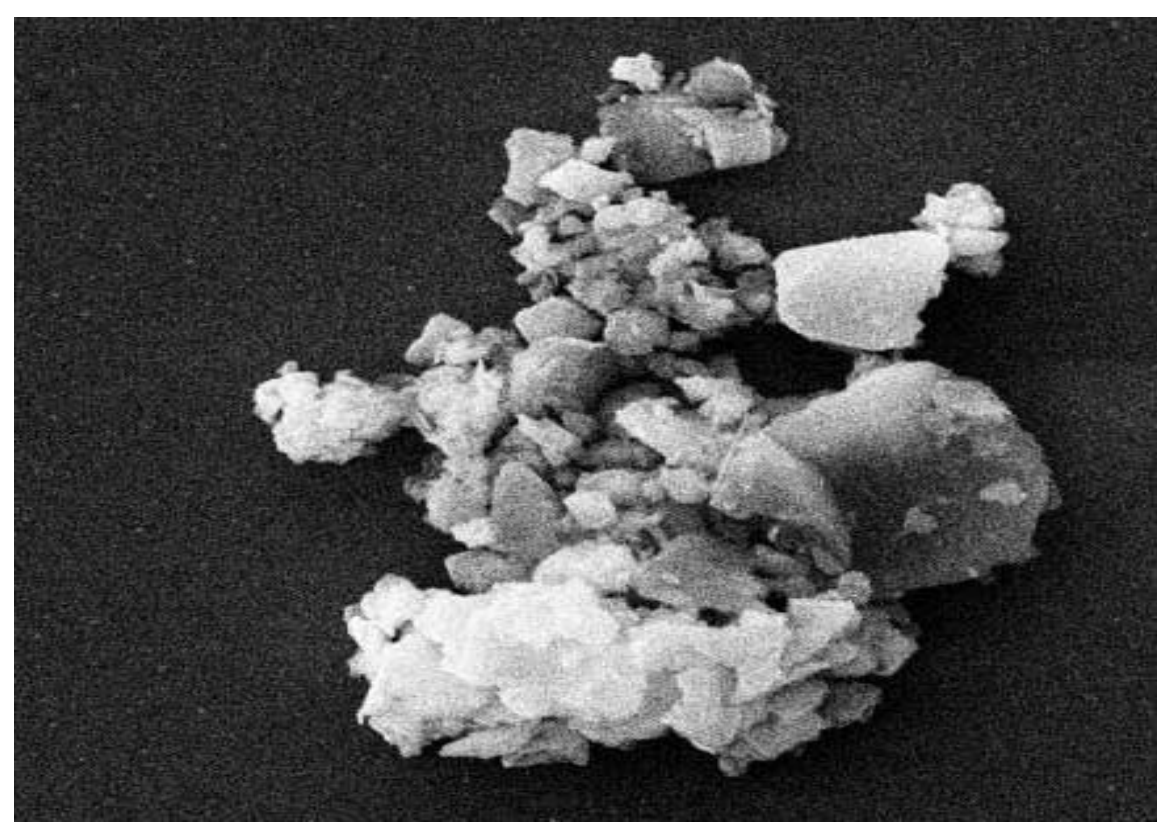

Fig. (4): Scanning electron microscopy of the particles of (CKD)

Free lime is found in (CKD). The concentration of free lime is generally highest in the coarser particles of (CKD) captured closest to the kiln. Finer particles of (CKD) contain higher 
concentrations of sulfates and alkalis. The primary value of cement kiln dust is its cementitious property. Depending on the concentration of lime $(\mathrm{CaO})$, (CKD) can be highly cementitious. Therefore, $(\mathrm{CKD})$ can be used as a replacement for other cementitious materials such as portland cement, blast furnace slag cement, Portland Pozzolan cement, blended cements [3].

There are currently many challenges to the utilization of by-product cement kiln dusts (CKD) as partial replacement of Portland cement. (CKD) is a fine powder (CKD typically have between 80 and $90 \%$ passing a $90 \mu \mathrm{m}$ sieve) that are generated during the cement manufacturing process, then carried off in the flue gases, and subsequently collected in baghouses or electrostatic precipitators. The portion of (CKD) that are not returned back to the cement manufacture process, or otherwise used beneficially, are placed in stockpiles or landfills. A limited number of studies have shown that (CKD) removed from the cement manufacturing process could be used as partial replacements of (PC) in the range of $(5-15) \%$, by mass. Although standards allow the use of (CKDs) at low levels of (PC) replacement, very little is known about the effects of different (CKDs) in pastes, mortars, and concrete [7].

There are many advantages of using cement kiln dust in concrete materials are as given below [3]:

- Opens a value added use option for utilization of (CKD)

- Helps in sustainable development by reducing demand of new landfills

- Uniform finer particle size is useful in manufacturing self-consolidating concrete and high-performance concrete

- Improves corrosion resistance of reinforcing steel in concrete

- Manufacturing of blended cement

The study of (CKD) as a partial replacement of (PC) has been an intermittent research area for the past (30) years. The studies that have been published on the use of (CKD) as a partial substitute for (PC) often report conflicting effects and mechanisms [7].

\section{EXPERIMENTAL PROGRAM}

This part deals with the various materials used in the present investigation, their choice, grading and relevant properties. It also desicribes the tests performed and the selected specifications for the experimental part of the research.

\subsection{Materials}

The materials used throughout this research included cement, cement kiln dust (CKD), fine aggregate, and coarse aggregate, with no additives used.

\subsubsection{Cement}

A manufactured Turkish cement known as "Cemko" brand from Cemko cement factory in "Turkey" is used during this study. The cement used complies with Iraqi specifications (IQS, No.5, 1984). The physical and chemical properties are given in tables (1) and (2), respectively. 
Hassan: Utilization of Cement Kiln Dust (CKD) as a Partial Replacement ----

Table (2): Physical Properties of the Cement Used

\begin{tabular}{|c|c|c|}
\hline Property & Test Result & Standard (IQS, No.5, 1984) \\
\hline $\begin{array}{c}\text { Fineness (Residue on sieve } \\
\text { No.170) }\end{array}$ & $2 \%$ & $10 \%$ (max) \\
\hline $\begin{array}{c}\text { Initial setting time } \\
\text { (minute) }\end{array}$ & 180 & 60 (min) \\
\hline $\begin{array}{c}\text { Final setting time } \\
\text { (minute) }\end{array}$ & 270 & \\
\hline Specific gravity & 3.14 & 16.0 \\
\hline $\begin{array}{c}\text { Compressive strength } \\
\text { (MPa): }\end{array}$ & & 24.0 \\
at 3days & 21 & \\
at 7days & 29 & \\
\hline
\end{tabular}

Table (3): Chemical Properties of Cement Used

\begin{tabular}{|c|c|c|c|c|c|}
\hline $\begin{array}{c}\text { Chemical } \\
\text { Composition }\end{array}$ & $\begin{array}{c}\text { Value } \\
(\%)\end{array}$ & $\begin{array}{c}\text { Standard (IQS, } \\
\text { No.5, 1984) }(\%)\end{array}$ & $\begin{array}{c}\text { Chemical } \\
\text { Composition }\end{array}$ & $\begin{array}{c}\text { Value } \\
(\%)\end{array}$ & $\begin{array}{c}\text { Standard (IQS, } \\
\text { No.5, 1984) (\%) }\end{array}$ \\
\hline $\mathrm{SiO}_{2}$ & 20 & $17-25$ & $\mathrm{C}_{3} \mathrm{~A}$ & 1.65 & Min. 5 \\
\hline $\mathrm{AL}_{2} \mathrm{O}_{3}$ & 4.05 & $3-8$ & $\mathrm{C}_{4} \mathrm{AF}$ & 16.33 & ---- \\
\hline $\mathrm{Fe}_{2} \mathrm{O}_{3}$ & 5.37 & $0.5-6$ & Solid Solution & 17.64 & ---- \\
\hline $\mathrm{CaO}$ & 64.6 & ---- & L.S.F & 0.9939 & ---- \\
\hline $\mathrm{MgO}$ & 2.95 & Max. 4 & Free Lime & 1.18 & ---- \\
\hline $\mathrm{SO}_{3}$ & 0.93 & Max. 3 & Loss on Ignition & 1.58 & ---- \\
\hline $\mathrm{C}_{3} \mathrm{~S}$ & 74.87 & ---- & Insoluble Residue & 0.8 & Max. 1.5 \\
\hline $\mathrm{C}_{2} \mathrm{~S}$ & 0.86 & ---- & & & \\
\hline
\end{tabular}

\subsubsection{Cement Kiln Dust (CKD)}

Table (4), shows the chemical composition of (CKD), the fine powder collected from the pre-heater section of the Badoosh Tawsee cement factory:

Table (4): Chemical Properties of the (CKD) Used

\begin{tabular}{|c|c|}
\hline $\begin{array}{c}\text { Chemical } \\
\text { Composition }\end{array}$ & $\begin{array}{c}\text { Value } \\
(\%)\end{array}$ \\
\hline $\mathrm{SiO}_{2}$ & 15.53 \\
\hline $\mathrm{AL}_{2} \mathrm{O}_{3}$ & 3.83 \\
\hline $\mathrm{Fe}_{2} \mathrm{O}_{3}$ & 3.05 \\
\hline $\mathrm{CaO}$ & 49.96 \\
\hline $\mathrm{MgO}$ & 1.69 \\
\hline $\mathrm{SO}_{3}$ & 7.18 \\
\hline $\mathrm{LOI}$ & 12.96 \\
\hline
\end{tabular}




\subsubsection{Mixing Water}

Ordinary drinking (tap) water was used for mixing.

\subsubsection{Fine Aggregate}

Coarse sand in accordance with (BS 882 : 1992) was used in this investigation, available in the "Kanhash" area. The sieve analysis is listed in table (5).

Table (5): Sieve Analysis of Fine Aggregate

\begin{tabular}{|c|c|c|c|c|c|}
\hline \multirow{2}{*}{$\begin{array}{c}\text { Sieve } \\
\text { Size } \\
(\mathrm{mm})\end{array}$} & \multicolumn{5}{|c|}{ \% Passing on each Sieve } \\
\cline { 4 - 6 } & \multirow{2}{*}{$\begin{array}{c}\text { L/A) } \\
\text { Limits }\end{array}$} & \multirow{2}{*}{$\begin{array}{c}\text { \% Passing of } \\
\text { the Sample }\end{array}$} & Coarse (C) & Medium (M) & Fine (F) \\
\hline 4.76 & 100 & 95 & - & - & - \\
\hline 2.36 & $89-100$ & 81.2 & - & - & - \\
\hline 1.18 & $60-100$ & 67.2 & $60-100$ & $65-100$ & $80-100$ \\
\hline 0.6 & $30-100$ & 47.9 & $30-90$ & $45-100$ & $70-100$ \\
\hline 0.3 & $15-100$ & 20.8 & $15-54$ & $25-80$ & $55-100$ \\
\hline 0.15 & $5-70$ & 6.6 & $5-40$ & $5-48$ & $5-70$ \\
\hline
\end{tabular}

\subsubsection{Coarse Aggregate}

Local coarse aggregate, available in (Laboratory of Testing of Construction Materials) was used in the research, round river gravel ( $\max$ size $10 \mathrm{~mm}$ ).

\subsection{Mix Proportions and Specimens Preparation}

The cement pastes, mortars and concrete mixes were prepared maintaining the levels of replacement of (CKD) of $(5,10,15,20,25,30) \%$ by weight of cement. A reference cement paste, mortar and concrete mix were also prepared for comparison. The blends were determined for their normal consistency and initial setting time according to (ASTM C187) and (ASTM C191) specifications of each cement paste respectively, while the compressive and tensile strengths of the cement mortars were tested according to (ASTM C109).

The concrete mix proportion is chosen from trial mixes. The mix proportion is $1: 1.88: 2.61 / 0.45$ with a cement content of $(390) \mathrm{kg} / \mathrm{m}^{3}$ which gave a cube compressive strength of (56) MPa at the age of (28) days. The aggregate used was (saturated surface dry). The consistency (workability) of fresh mixes was evaluated by slump test according to (BS 1881: Part 102: 1983). For each mix, cube specimens (100x100x100) mm and cylinder specimens $(100 \times 200) \mathrm{mm}$ were prepared in the laboratory. All the fresh mixes were placed into the molds, and kept for about (24) hrs in the laboratory and demolded, and moist cured for $(3,7,28)$ days. The compressive strength of the concrete specimens was tested according to (BS1881:Part116: 1983), whereas the splitting tensile strength tested according to (ASTM C496) specification and given by the equation: 
$\mathrm{ft}^{\prime}=\frac{2 \mathrm{P}}{\pi \mathrm{DL}}$

where:

$\mathrm{P}=$ two equal compressive loads.

$\mathrm{D}=$ diameter of cylinder specimen.

$\mathrm{L}=$ length of cylinder specimen.

\section{RESULTS AND DISCUSSION}

\section{Cement Pastes}

1.1. Water at Standard Consistency: The water to binder ratio (w/b) at normal consistency was plotted against (CKD) content in Fig.(5).

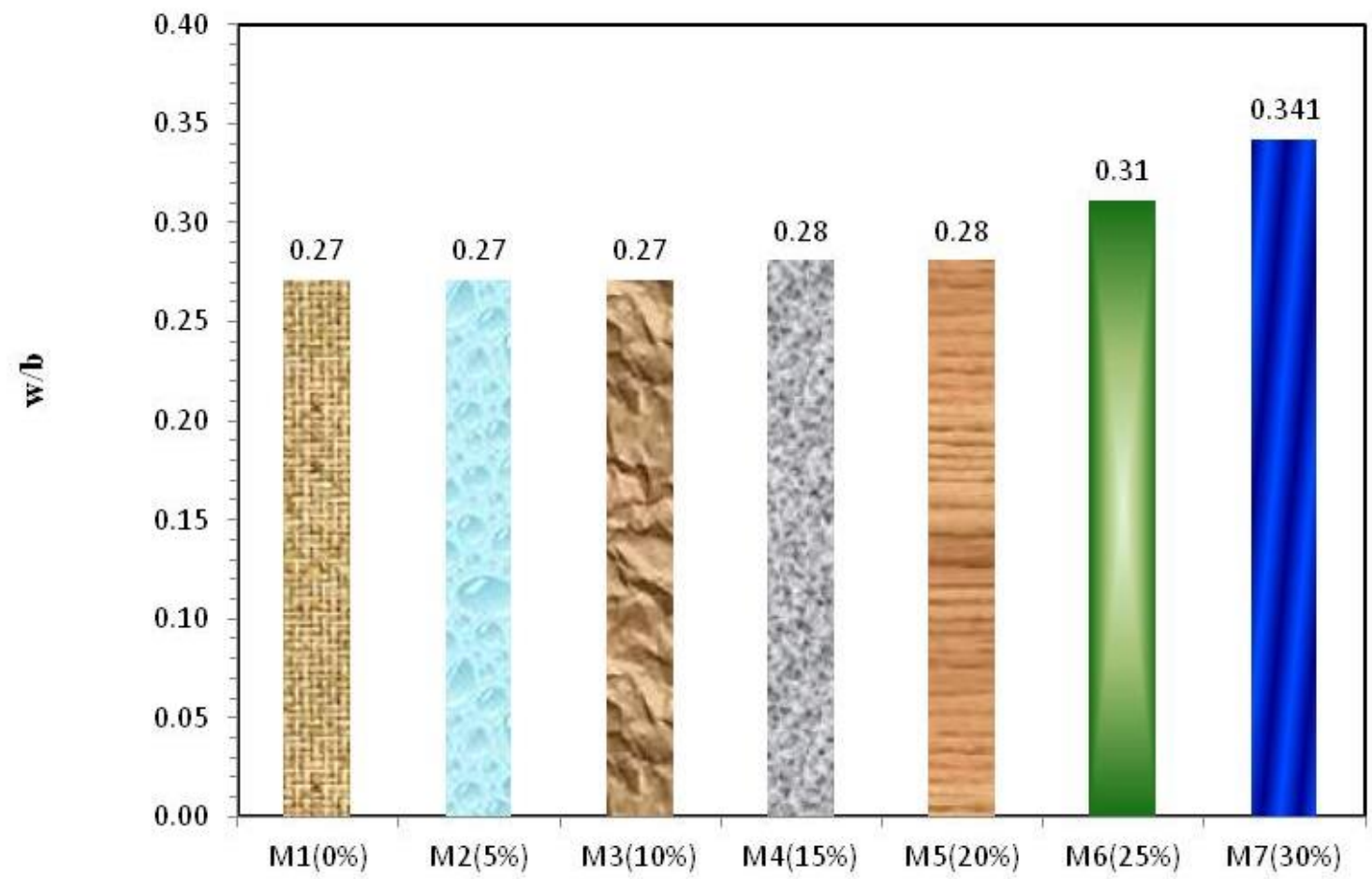

Fig. (5): Water to binder ratio of cement pastes

From Fig.(5), it is noted that a (w/b) ratio of the cement pastes with $(0,5,10) \%$ (CKD) content is $(0.27)$. The $(\mathrm{w} / \mathrm{b})$ marginally increased to $(0.28)$ at $(15,20) \%$ of $(\mathrm{CKD})$. While, the $(\mathrm{w} / \mathrm{b})$ increased to $(0.31)$ with $(25) \%(\mathrm{CKD})$ replacement of cement, and finally it increased to $(0.341)$ at $(30) \%(\mathrm{CKD})$ replacement. it is noticed that the water demand at normal consistency of blended cement pastes is higher than that for (OPC) paste and the addition of (CKD) increases the water demand at normal consistency. This may be attributed to high amounts of alkalis, sulfates, and volatile salts as well as the higher surface area of (CKD) that requires more water [6]. Increased fineness of a (CKD) may allow it to have more impact at early age of hydration in a (CKD-PC) blend by means of increased ion dissolution. Therefore, 
a (CKD-PC) binder that has increased chemical reactivity during early stages of hydration in comparison to the (OPC) alone may also have a higher water demand [7].

1.2. Initial Setting Time: The results of the initial setting time are plotted as a function of (CKD) content in Fig.(6):

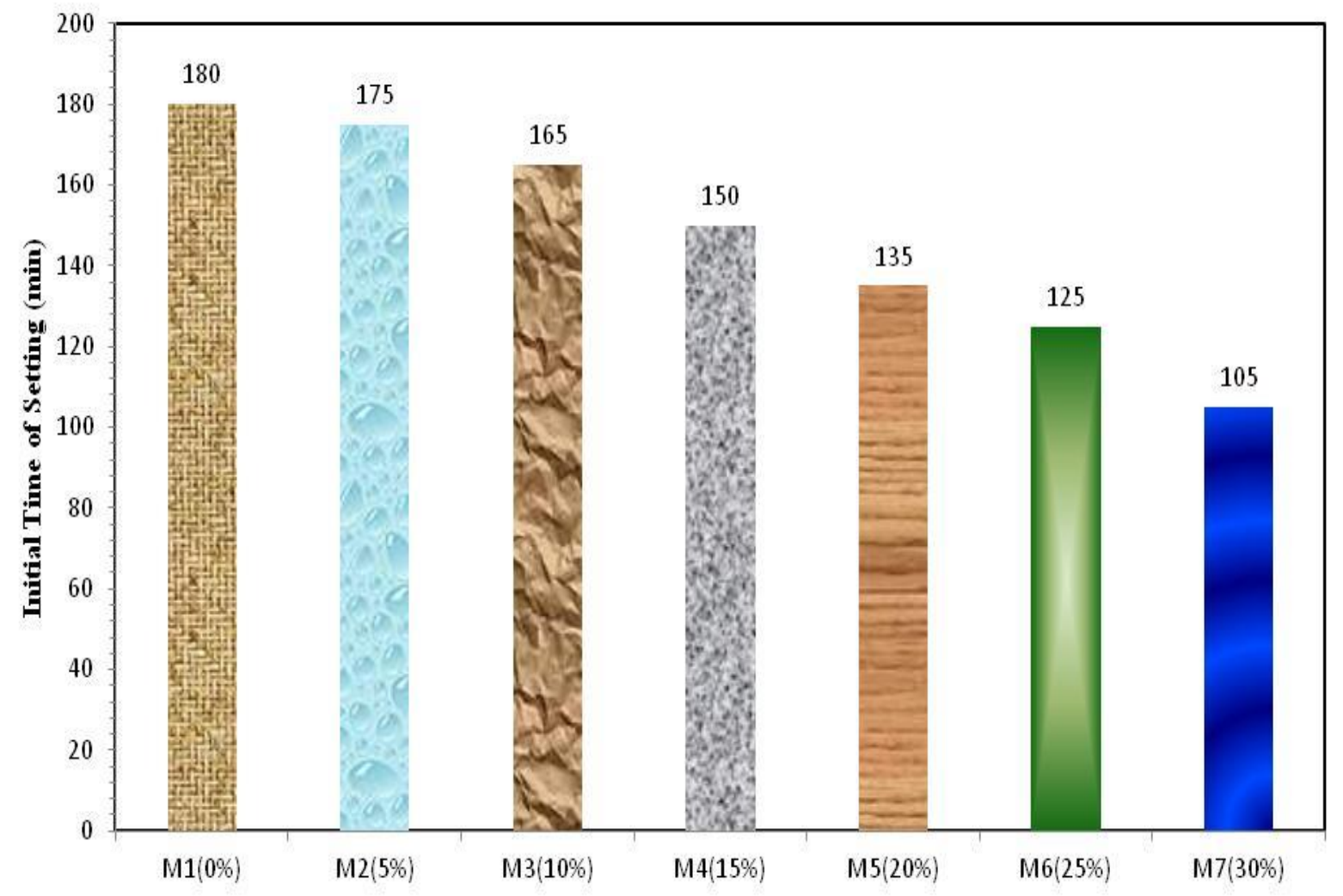

Fig. (6): Initial setting time of blended cement pastes

The initial setting times of blended cement pastes are less than that for (OPC) paste. As the (CKD) replacement increases, the setting time decreases. This is also due to the high amounts of lime and alkalis in (CKD), which accelerate the hydration process, leading to a fast setting. Generally, the addition of (CKD) accelerates the hydration process and reduces the setting times of the blended cement [6]. Also, the setting time impact of (CKD) is likely to be a function of the total composition of the (CKD-OPC) blend [7].

\section{Mortars}

2.1. Compressive Strength: The compressive strength of the hardened cement mortars containing (OPC) with different amounts of (CKD) is graphically represented as a function of curing time in Fig.(7). The compressive strength increased with age for all hardened cement mortars. 


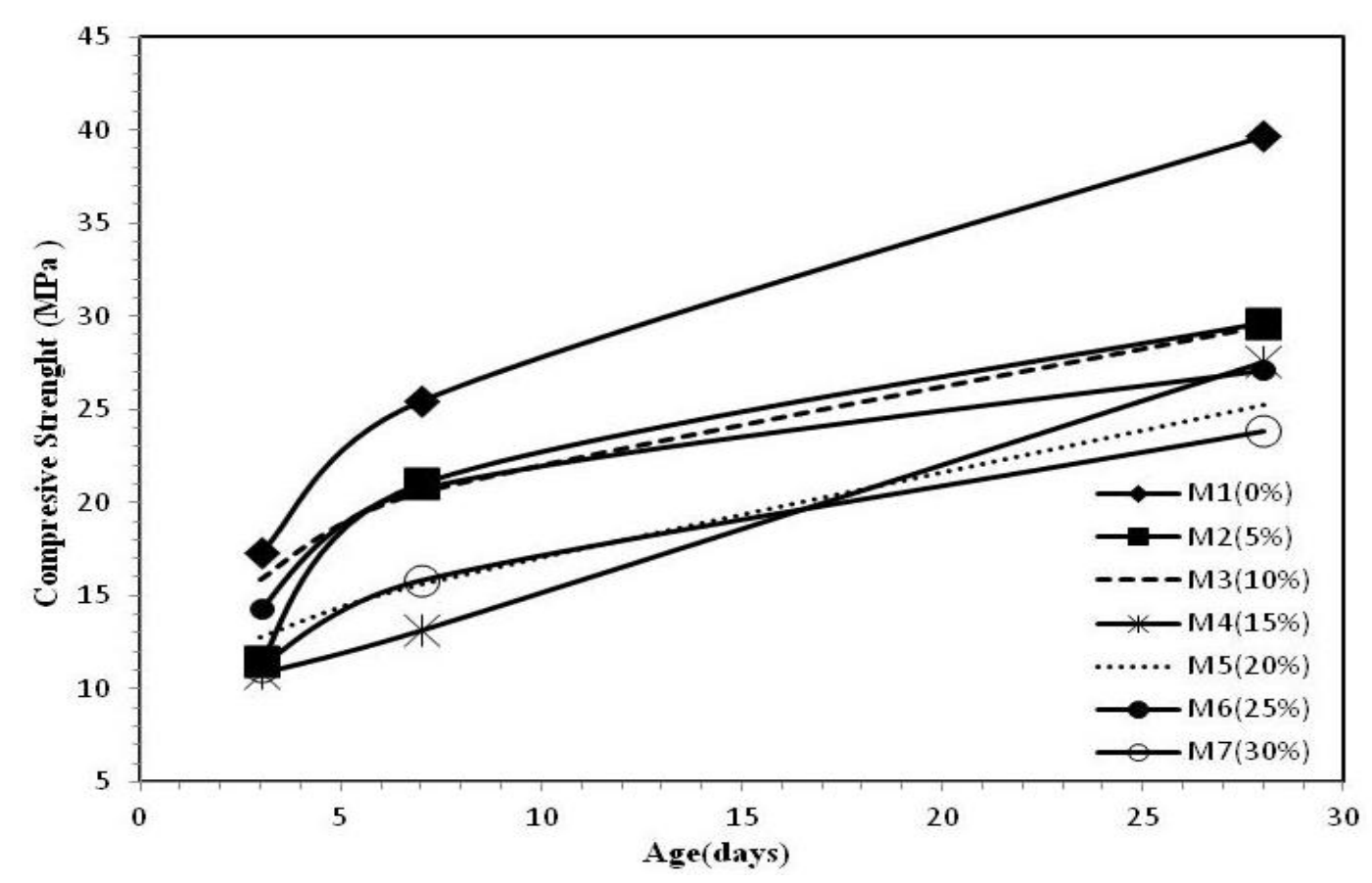

Fig. (7): Compressive strength of blended cement mortars with age

A major observation was that there is generally a decrease in compressive strength with an increase in (CKD) replacement for cement. From Fig.(7), it appeares that the mortars $\left(\mathrm{M}_{3}\right.$, $\left.\mathrm{M}_{6}\right)$ incorporating $(10,25) \%(\mathrm{CKD})$ had the higher compressive

strengths than the other mixes in comparison to $\left(\mathrm{M}_{1}\right)(0 \% \mathrm{CKD})$ at (3) days. At (7) days, the levels $(5,25) \%(\mathrm{CKD})$ in the mixes $\left(\mathrm{M}_{2}, \mathrm{M}_{6}\right)$ maintened higher compressive strength than all mortars in comparison to $\left(\mathrm{M}_{1}\right)(0 \% \mathrm{CKD})$. Also, at (28) days the mortars $\left(\mathrm{M}_{2}, \mathrm{M}_{3}\right)$ satisfied the higher compressive strength which reached to $(29.6,29.5) \mathrm{MPa}$ respectively, however these values are less than the compressive strength of the reference mortar alone (39.7) MPa. It can be concluded that the substitution of the ordinary cement with (5) $\%$ to (10) \% (CKD) has a slight effect on the compressive strength. The reduction of compressive strength is attributed to the reduction in the cement content and an increase in the water to cement ratio as well as the increase in free lime content in cement dust; the higher amount of $\mathrm{Ca}(\mathrm{OH})_{2}$ weakened the hardened matrix.

Also, the formation of chloro- and sulfoaluminate phases leads to the softening and expansion of the hydration products. The formation of these products enhances the crystallization of hydration products leading to an opening of the pore system [6]. The crystallization of hydration products may be accompanied by an increase in the pore size due to change in the packing between the crystals, which leads to a decline in the strength. It can be said that the replacement of (CKD) dust up to (5) \% in (OPC) can be utilized for the manufacture of the blended cement [6].

2.1. Tensile Strength: The tensile strength of the hardened cement mortars prepared with (CKD) is graphically represented in Fig. (8). 


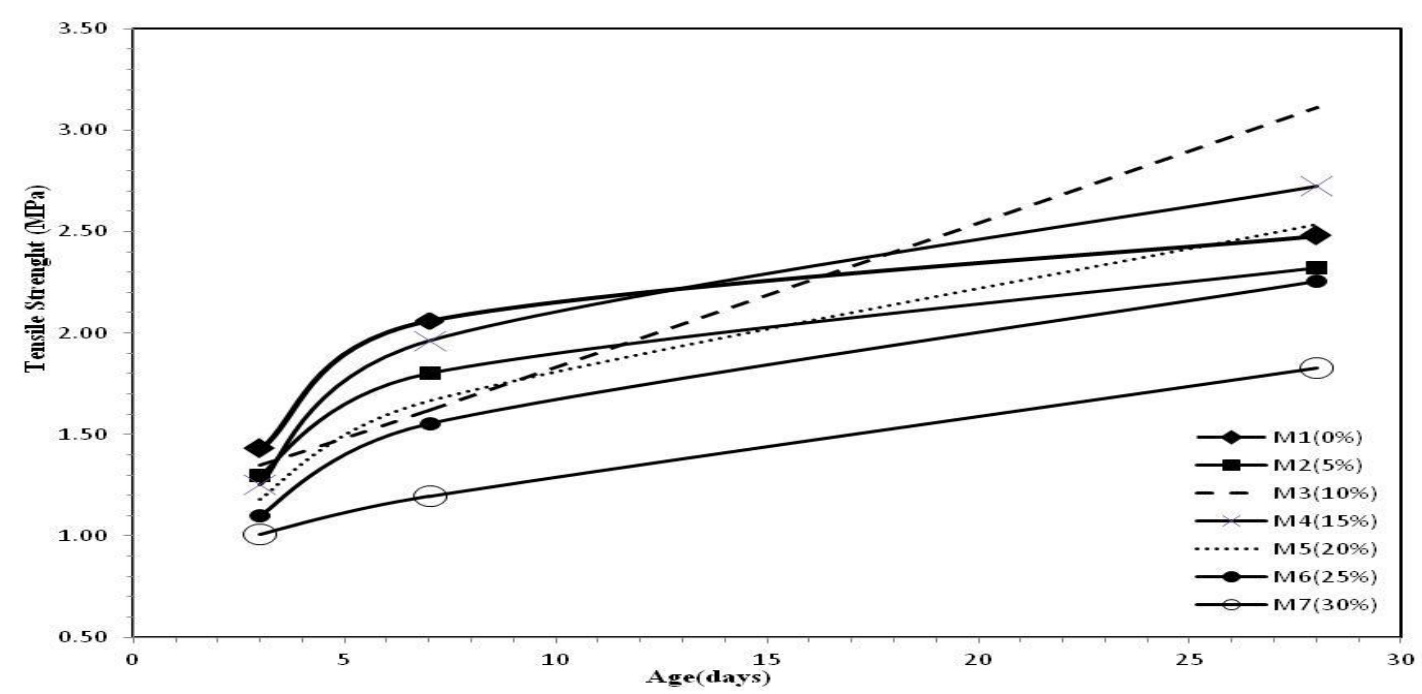

Fig. (8): Tensile strength of cement mortars with curing age

The test results indicate that at (3) days, the tensile strength of of $\left(\mathrm{M}_{3}\right)$ containing (10 $\% \mathrm{CKD}$ ) is the highest, whereas the best tensile strengths were observed at (15\% CKD) substitution at $(7,28)$ days, especially at $(28)$ days, the tensile strength of the mortar $\left(\mathrm{M}_{4}\right)$ of (2.73) $\mathrm{MPa}$ is larger than the reference mortar (2.48) MPa. Similar to the effects on compressive strength, it was stated that the tensile strength values decreased with an increase in (CKD) replacement, but at (15\%) replacement level it has appreciable adverse effect (especially at 28 days). It was stated that it is commonly accepted that the low hydraulic property of (CKD) causes the compressive strength to decrease as the amount of (CKD) replacement increases. So, it was also suggested that the increased strength in the specimen with (15\% CKD) may be attributed to an appropriate alkalinity that increases the dissolution of silicate species and formation of $(\mathrm{C}-\mathrm{S}-\mathrm{H})$ as well as noting that $(15 \% \mathrm{CKD})$ replacement of (OPC) significantly reduces the volume fraction of pores larger than $(3 \mu \mathrm{m})$, which may result an improved strength [7]

\section{Concrete}

3.1. Workability: The influence of the addition of (CKD) on the slump (consistency test) of the fresh concrete mixes was shown in Fig. (9).

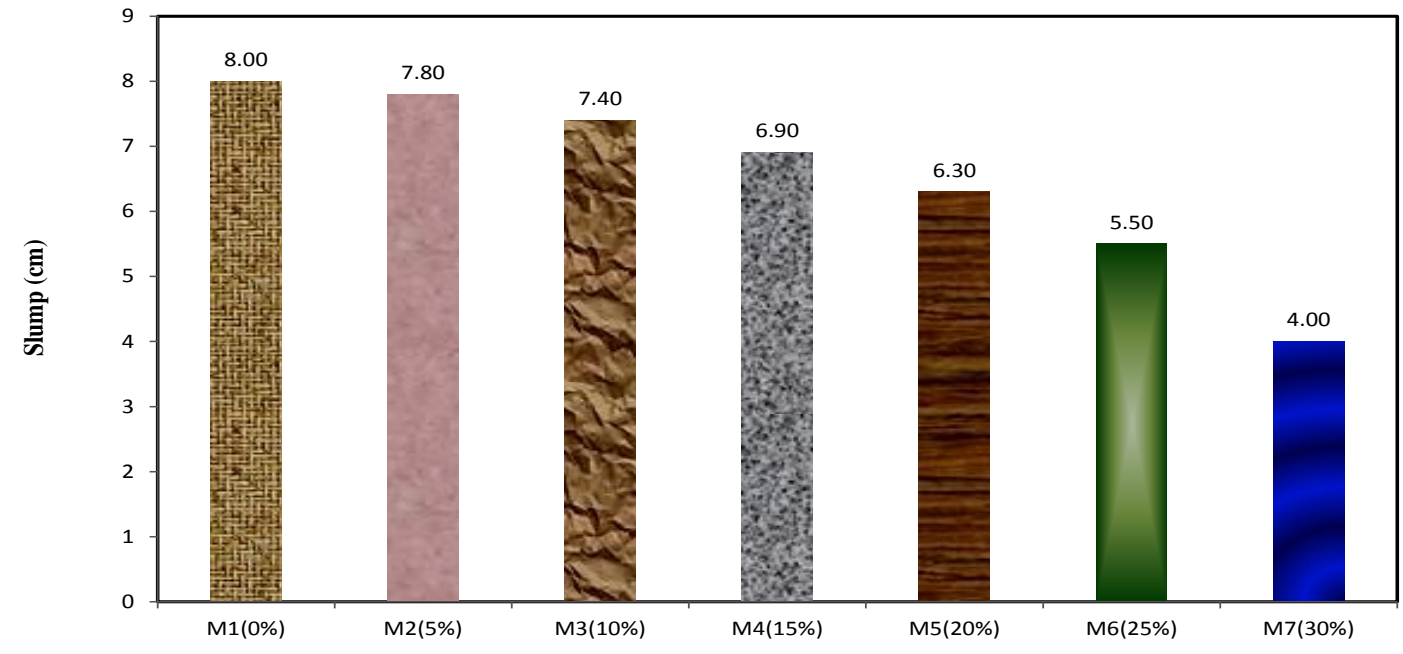

Fig. (9): Slump results of concrete mixes 
From Fig.(9), It is noted that the workability (slump) of the concrete mixes decreased as the content of (CKD) increased. The majority of researchers found that, the trend was somewhat linear until a plateau was reached. The suggested reasons for a reduction in workability when (CKD) is used as a partial substitute for (OPC) vary considerably: (CKD) alkali content, chloride content, sulfate and volatile salts content, lime content, a high fineness of (CKD), rapid ion dissolution, high coarseness of (CKD), particle size, and lower density of (CKD). It is interesting to note that both higher fineness (based upon Blaine fineness) and higher coarseness (based upon particle size distribution) of (CKD) compared to cement were suggested to have the same impact of reducing workability of pastes [7].

3.1. Compressive Strength: Each of the various blended concrete mixes along with the reference mix was tested for compressive strength after $(3,7,28)$ days. The test results are shown in Fig. (10).

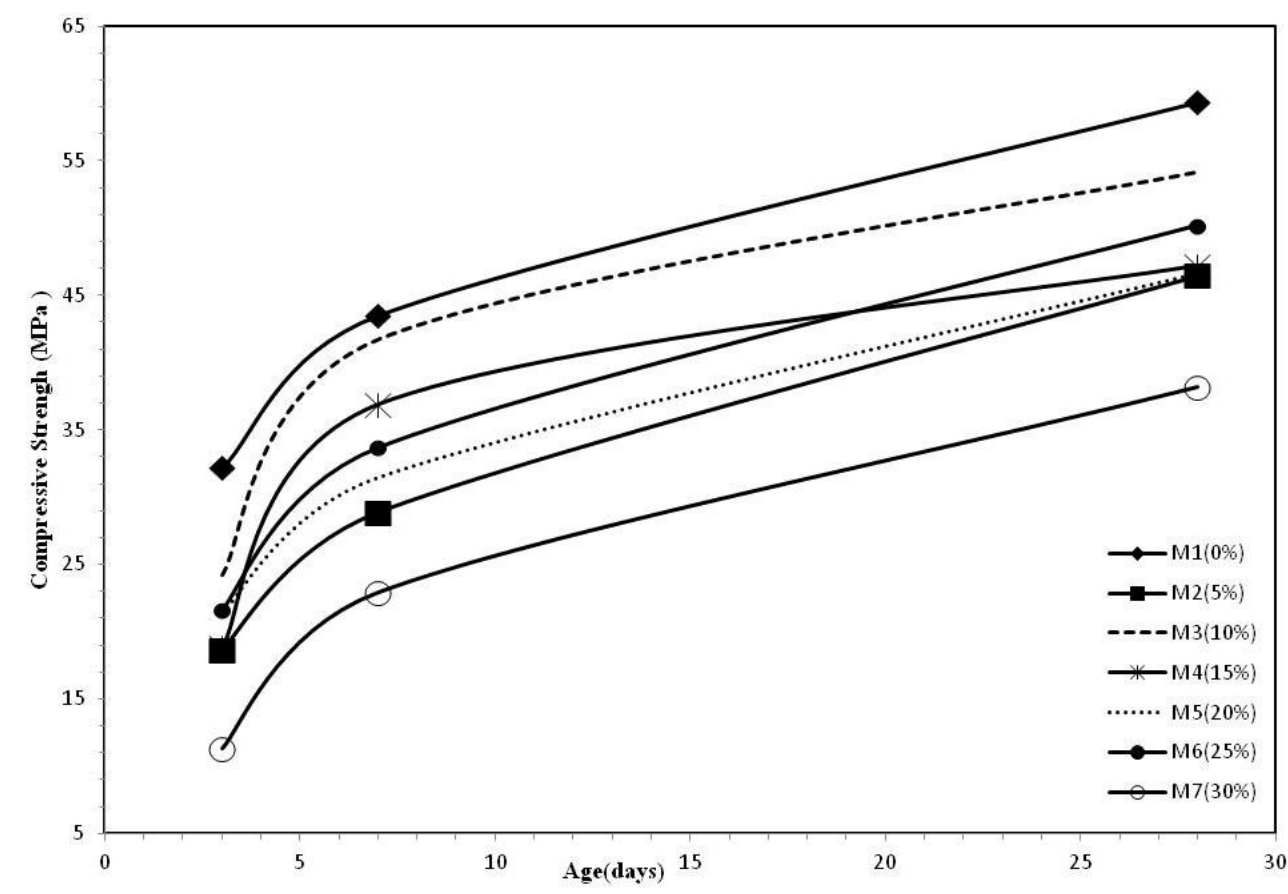

Fig. (10): Compressive strength of concrete specimens with age

The results demonstrated that $\left(\mathrm{M}_{3}\right)$ incorporating $(10 \% \mathrm{CKD})$ had the highest compressive strengths of $(24.2,41.7,54.2) \mathrm{MPa}$ at ages $(3,7,28)$ days respectively, compared to that in the reference mix alone of $(32.2,43.5,59.3) \mathrm{MPa}$. Four possible mechanisims may be cited to explain the impact of (CKD) replacement of ordinary cement on compressive strength in these tests $[10,7]$ :

- High alkali contents results into increased susceptibility to alkali - aggregate reaction, which may be blocked by the slag or fly ash constituents. Alkalis in the (CKD) may modify the nature and strength of the cement hydration products.

- Since the (CKD) dust particles are finer than cement, the hydration of the cementitious particles in the dust may occur at a faster rate than the (OPC). From the results, this 
was noted by the development of strength with age expressed as a percentage of its 28 day strength for the control and (CKD) blended mixes. In general, the concrete without (CKD) replacement showed the lowest percentage of (28) days strength at early ages when compared with the (CKD) concrete.

- The portion of (CKD) that is not cementitious may act as a fine filler and contributes to an increase in strength through increased compaction or provision of nucleation sites for cement hydration.

The presence of (CKD) causes the paste to become weaker, and as the paste strength weakens, the aggregate-cement paste bond also weakens [7]. Alternatively, concrete mixtures with high replacement levels of (CKD) may be utilized to produce low strength concrete provided it is established that such a replacement does not affect its durability [11].

3.2. Splitting Tensile Strength: The splitting tensile strength of the concrete specimens prepared with or without (CKD) is depicted in Fig. (11).

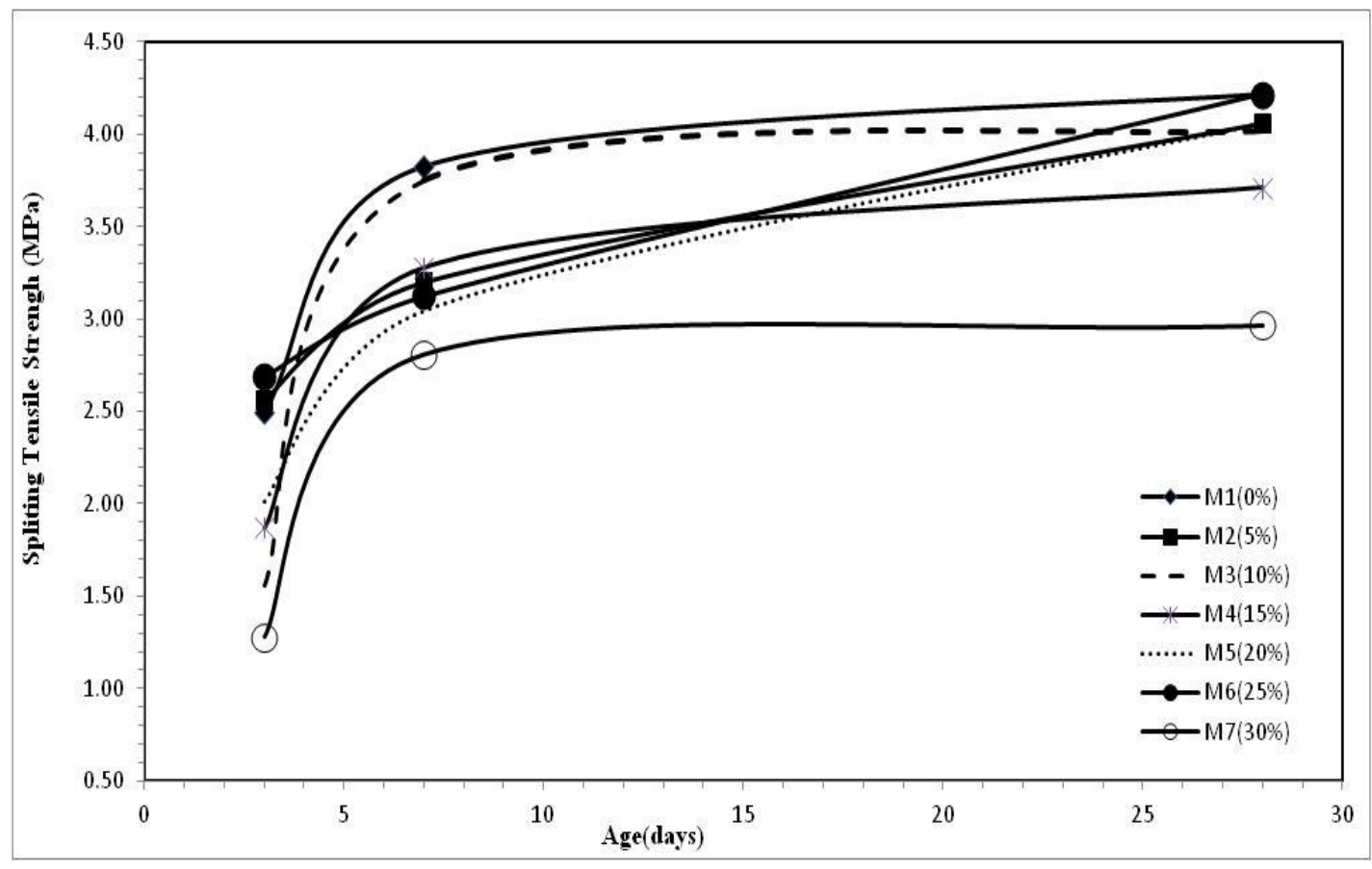

Fig. (11): Splitting tensile strength of concrete specimens with age

It is noted that a gradual decrease in the splitting tensile strength occurs for the concrete samples as the amount of (CKD) increased. The 7-day splitting tensile strength of (CKD) concrete was the higher at mix $\left(\mathrm{M}_{3}\right)$ with $(10 \% \mathrm{CKD})$ than for the other mixes. But at $(3,28)$ days, the figure showed that mix $\left(\mathrm{M}_{6}\right)$ with $(25 \% \mathrm{CKD})$ gave the largest values of the splitting tensile strengths of $(2.69,4.21) \mathrm{MPa}$, respectively. Generally, many of the suggested mechanisms for the reduction in flexural and splitting tensile strengths were the same as the mechanisms for the reduction in compressive strength [7]. The reduction in tensile strength was attributed to the alkalis which may modify the hydration products as well as to (CKD) may act as a fine filler and the presense of it weakened paste and aggregate - paste bond [7]. 


\section{CONCLUSIONS}

Based upon the experimental study, the following conclusions can be drawn:

1) Cement kiln dust (CKD) can be effectively used as a blended cement material.

2) The addition of (CKD) increases the water demand for normal consistency of the cement pastes, whereas the setting time decreases.

3) The increase of (CKD) amount, reduces the workability of fresh mixes and also the strength of the hardened mortars and concretes, generally.

4) The optimum content of (10\% CKD) acts an activator for compressive strength of the mortars and concretes. This content showed comparable strength to the strength of the reference mixes at all ages, therefore it is advisable to restrict the quantity of (CKD) to (10 $\%)$, as a replacement of cement from strength.

5) Generally, the tensile strength develops faster than compressive strength at early ages, so that the substitution of ordinary cement with (10\% CKD) has a significant effect on the tensile strength of mortars and concretes at early ages ( 3 days for mortars and 7 days for concretes), while the level of replacement (15\% CKD) has a better behavior to mainten the higher tensile strength of mortars at $(7,28)$ days. Besides, the level of $(25 \% \mathrm{CKD})$ replacement makes the same effect for concretes at $(3,28)$ days compared to the reference mixes.

\section{REFERENCES}

[1] Shah, S.P. and Wang, K., "Development of Green Cement for Sustainable Concrete Using Cement Kiln Dust and Fly Ash", International Workshop on Sustainable Development and Concrete Technology, USA, pp.15-23.

[2] Adaska, W.S. and Taubert, D.H., "Beneficial Uses Of Cement Kiln Dust", Presented to IEEE / PCA 50th Cement Industry Technical Conference, Miami, FL, May 19-22, 2008, pp.1-19.

[3] Naik, T.R., Canpolat, F. and Chun, Y.M.," Uses of CKD other than for Flue Gas Desulfurization", Center for by- products utilization, A CBU Report for Holcim (US), Report No. CBU-2003-35, 2003, pp.1-33.

[4] "Beneficial Use of Industrial By-Products", Identification and Review of Material Specifications, Performance Standards, and Technical Guidance, Madison, Prepared For Inc. / NCASI Working Copy, 2003, pp.1-65

[5] Williams, R.J., " Effects of Cement Kiln Dust (CKD) Chemistry and Content on Properties of Controlled Low-Strength Materials (CLSM)", M.Sc Thesis, University of South Carolina, 2005, pp.1-100.

[6] El-Aleem, S.A., Abd-El-Aziz, M.A, Heikal, M. and El Didamony, H., "Effect of Cement Kiln Dust Substitution on Chemical and Physical Properties and Compressive Strength of Portland and Slag Cements", The Arabian Journal for Science and Engineering, Vol.30, No.2, 2005, pp.263-273.

[7] Khanna, O.S., "Characterization and Utilization of Cement Kiln Dusts (CKDs) as Partial Replacements of Portland Cement", Ph.D Thesis, University of Toronto, 2009, pp.1-323. 
[8] Colangelo, F., Vaccaro, R. and Cioffi, R. ," Life Cycle Assessment of Sustainable Concrete Made With Recycled Aggregates", Proceeding in $2^{\text {th }}$ International Conference on Sustainable Construction Materials and Technologies, June 28-30, 2010, Italy.

[9] Rahman, M. K., Rehman, S. and Al-Amoudi, O. S. B., "Literature Review on Cement Kiln Dust Usage in Soil and Waste Stabilization and Experimental Investigation", Center of Engineering Researches, King Fahd University of Petroleum and Minerals, Saudi Arabia, IJRRAS, Vol.7, No.1, 2011, pp.77-87.

[10] Daous, M.A, "Utilization of Cement Kiln Dust and Fly Ash in Cement Blends in Saudi Arabia", JKAU: Eng. Sci., Vol.15, No.1, 2004, pp. 33-45.

[11] Maslehuddin , M., Al-Amoudi, O.S.B., Rahman, M.K., Ali, M.R., Barry, M.S., "Properties of Cement Kiln Dust Concrete", Construction and Building Materials, No.23, 2009, pp. 2357-2361. 